\title{
Evaluation of Students' Opinions Regarding Distance Learning Practices in Turkish Universities during the Covid-19 Pandemic
}

\author{
Covid-19 Pandemisi Sürecinde Türkiye'deki Üniversitelerde Uzaktan Öğretim Uygulamaları Hakkında \\ Öğrenci Görüşlerinin Değerlendirilmesi
}

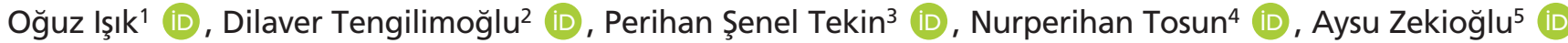 \\ ${ }^{1}$ Faculty of Economics and Administrative Sciences, Hacettepe University, Ankara, Turkey \\ ${ }^{2}$ Graduate School of Social Sciences, Atılım University, Ankara, Turkey \\ 3Vocational School of Health, Ankara University, Ankara, Turkey \\ 4Faculty of Health Sciences, Sivas Cumhuriyet University, Sivas, Turkey \\ ${ }^{5}$ Faculty of Health Sciences, Trakya University, Edirne, Turkey
}

\begin{abstract}
Özet
Bu çalışmanın amacı, Türkiye'deki üniversitelerin öğrencilerinin uzaktan eğitim sürecinde zorluk yaşayıp yaşamadıklarını ve sistemle ilgili görüşlerinin neler olduğunu belirlemektir. Kesitsel tarama yöntemi kullanılarak, bu araştırmanın verileri 5052 üniversite öğrencisinden elde edilmiştir. Araştırmadan toplanan verilere göre öğrencilerin \%58.5'inin üniversitelerinde asenkron uzaktan eğitim dersleri bulunmaktadır. Uzaktan eğitim sınıflarına erişimle ilgili olarak öğrencilerin kendilerine atfedilebilecek problemler bilgisayarlardan ve internetten kaynaklanırken, sistemle ilgili problemler çoğunlukla bağlantı sorunları ve derslerin çok erken veya çok geç olmasıydı. Katılımcıların \%73.7'si öğretim elemanları tarafindan uzaktan eğitim sistemlerine yüklenen ders materyallerini yeterli veya kısmen yeterli bulurken, \%36.7'si ödevleriyle ilgili kaynaklara erişimde sorun yaşadıklarını belirtmiş̧tir. Öğrencilerin uzaktan eğitim sisteminden memnuniyet düzeyi 10 puan üzerinden 4.4 olarak bulunmuştur. Katılımcıların memnuniyet düzeylerinin öğrenim gördükleri üniversitenin sahiplik türüne göre farklılaşıp farklılaşmadığına ilişkin değerlendirmeye göre öğrencilerin memnuniyet düzeyi genel olarak düşük olmakla birlikte vakıf üniversitelerinde (4.9 puan) devlet üniversitelerine göre (4.3 puan) daha yüksektir.
\end{abstract}

Anahtar sözcükler: Covid-19 süreci, lisans öğrencileri, uzaktan eğitim, yükseköğretim.

$\mathrm{H}$ aving started in December 2019 in China and later turning into a global outbreak, the Covid-19 pandemic has deeply affected education as it did all other areas beyond health. One of the first measures adopted by many governments from the United States to Europe was to

\begin{abstract}
The purpose of this study is to identify whether students at Turkish universities are having difficulties in the distance learning process and to reveal their opinions regarding the system. Using a cross-cultural survey design, data were collected from 5052 students. Based on the collected data, $58.5 \%$ of the students have asynchronous distance learning classes in their universities. Access to distance learning classes is one of the problems, and it is attributed to computers, internet, and connectivity issues as well as with starting the lessons too early or late. A majority of participants $(73.7 \%)$ found class materials uploaded by lecturers to distance learning systems to be sufficient or partially sufficient, and $36.7 \%$ stated that they had problems accessing resources regarding their homework. Students' satisfaction level with the distance learning system scored 4.4 out of 10 . According to the evaluation regarding whether the level of satisfaction of participants varied across the type of university, the satisfaction level of students in public universities is generally low (score of 4.3 out of 10) compared to satisfaction in foundation universities $(4.9$ out of 10$)$.
\end{abstract}

Keywords: Covid-19 period, distance learning, higher education, student satisfaction, undergraduate students.

stop the conventional face-to-face learning system by enforcing social distancing rules to prevent the spread of the virus while protecting individuals. In this scope, digital or distance learning was seen as a saviour and an alternative to conventional education methods.

\footnotetext{
İletişim / Correspondence: Assoc. Prof. Oğuz Işık, PhD Department of Health Management, Faculty of Economics and Administrative Sciences, Hacettepe University, Beytepe 06800 Ankara,Turkey e-mail: oguzisik@hacettepe.edu.tr
}

Yükseköğretim Dergisi / Journal of Higher Education (Turkey), 11(3), 607-616. () 2021 Deomed Geliş tarihi / Received: Haziran / June 19, 2020; Kabul tarihi / Accepted: Aralık / December 3, 2020 Bu makalenin atıf künyesi / How to cite this article: Ișık, O., Tengilimoğlu, D., Senel Tekin, P., Tosun, N., \& Zekioğlu, A. (2021). Evaluation of students' opinions regarding distance learning practices in Turkish universities during the Covid-19 pandemic. Yükseköğretim Dergisi, 11(3), 607-616. doi:10.2399/yod.20.006000 
Therefore, with the Covid-19 pandemic period, the dawning of the new millennium had witnessed the initial entry of the Next Generation into our higher education institutes, which required staff to brace themselves for a new generation of learners who had specific interests and dispositions. Their entry into the world was when technological expansion was ubiquitous and widely adopted worldwide (Ali, 2020).

Although criticised by many pedagogies that assert that it cannot be a substitute for conventional face-to-face education, distance education today is an education model experienced by many institutions despite all doubts (Zhou, 2016). Distance education by itself can be an alternative to face-to-face education for some fields, while in other areas, it can be complementary to face-to-face education. In this context, its advantages over face-to-face education and its weaknesses must be considered when making decisions about distance education.

While distance education is defended for its benefits and advantages over formal education, it is not immune to criticism. The most widely discussed criticism of distance education is its inability in deliver face-to-face interaction between students and other students, and between students and teachers. This is quoted as the main reason for dissatisfaction with distance education in many studies (Durak, Çankaya, Yünkül, \& Bozkurt, 2017). In a study from North America that compared formal education and online education in universities, the findings showed that participants believed that lecturer support was better in formal education, that academicians care about learning outputs more in formal education, and that they helped more in cases where students had any needs or problems (DesprésBedward, Avery, \& Phirangee, 2018).

In Turkey, the Covid-19 measures started with the emergence of the first case on 10 March 2020. In this scope, the decision was made that all classes and events of elementary, secondary, and higher education that had been thus far carried out face-to-face would be carried out online via the distance education method. In Turkey, 7.9 million students receive instruction from 207 universities. Committees formed under the coordination of the Council of Higher Education during pandemics rapidly launched their activities. Education and learning that had ceased on 16 March 2020, continued as of 23 March 2020 in the form of distance learning over a digital education infrastructure. The Council of Higher Education and universities guaranteed that education would be provided by using synchronous and asynchronous classes, taking advantage of information and communication technologies (such as television and the internet). While some universities used their own infrastructure for this process, other universities with no or insufficient learning management systems made their plans to use other university capabilities. Some universities created virtual classroom environments via Zoom or MS Teams, using Learning Management Systems (LMSs) such as Moodle or Blackboard, and some used their own designed platforms. Regarding class materials, a "Council of Higher Education Classes Platform" was also formed under the Council of Higher Education ${ }^{[1]}$ to enable joint use of universities' digital resources in an academic and cultural resource pool. Over two thousand open classroom materials can be accessed on this platform by anyone who desires access (Saraç, 2020).

In evaluating distance education during the pandemic period in Turkey's universities, the level of the teaching staff's integration with technology will shape the students' expectations and experience. This situation emerging worldwide will bring new paradigms in education processes (Karadağ \& Yücel, 2020).

Previously presented as an alternative to face-to-face education in limited areas and dependent on users' preferences, the distance education method was rapidly implemented in this pandemic and has become mandatory. The rapid advancement of the process has been a unique, challenging, and unexpected experience for many students and instructors, thereby creating a new situation that must be examined and understood in terms of user experiences and perceptions. This study evaluates the distance education method in higher education, which was inevitably adopted due to the Covid-19 pandemic, and examines students' satisfaction levels across some variables.

\section{Method}

We used a cross-sectional survey design in this study. With the onset of Covid-19 pandemic, all education institutions switched to mandatory distance education systems. This study is descriptive, aiming to determine the opinions of students studying in universities in Turkey about the distance education system during the Covid-19 pandemic. Moreover, this study aims to determine whether students' level of satisfaction of distance education systems varies depending on various variables. For this purpose, the following questions were asked within the scope of the research:

- What opportunities do students have within the distance education system?

- What kind of problems do students experience within the scope of the distance education system?

- Do students' satisfaction levels with the distance education system differ depending on the type of university where they study (public or foundation)?

- Do students' satisfaction levels with the distance education system differ according to the field of study?

[1] See https://www.yok.gov.tr/Documents/Kurumsal/egitim_ogretim_dairesi/Uzaktan_ogretim/yuksekogretim_kurumlarinda_uzaktan_ogretime_iliskin_usul_ve_esaslar.pdf 
Table 1. The universe and sample.

\begin{tabular}{lcccc} 
Universities & Total students & Layer weight & $\begin{array}{c}\text { Minimum } \\
\text { targeted students }\end{array}$ & $\begin{array}{c}\text { Number of students } \\
\text { participated in survey }\end{array}$ \\
\hline Public university & $7,320,449$ & 0.92 & 3833 & 4341 \\
Foundation university & 619,684 & 0.08 & 325 & 711 \\
Total & $7,940,133$ & 1.00 & 4158 & 5052 \\
\hline
\end{tabular}

The population of this study consists of 7,940,133 students that receive higher education in Turkey's public and foundation universities. Approximately $38 \%$ of these students are studying for an associate degree, $57 \%$ in an undergraduate programme, and $5 \%$ in postgraduate programmes. ${ }^{[2]}$ The sample of the research was selected from the public and foundation universities to obtain a nationwide sample. In calculating the sampling size, the formula proposed by Cochran (1977) was used. As a result of the calculation, the number of students included in the sampling with a confidence level of $99 \%$ and with an error margin of \pm 0.02 was determined as 4158. We collected data from 5052 students ( $\square$ Table 1). The fact that the number of questionnaires reached is more than the sample size calculated statistically, and the distribution of university students obtained from the sample is close to the distribution in the universe by state of education associate degree $31.9 \%$, undergraduate $65.4 \%$, and postgraduate programmes $2.7 \%$ ) suggest that the study sample has a good representation power of the universe.

A questionnaire was used as a data collection tool in this study. The questionnaire was prepared with the aid of the RedCap application (Research Electronic Data Capture), which consists of a digital data collection, management, and dissemination platform. The questionnaire includes statements (10 statements) to identify students' socio-demographic characteristics in addition to statements to establish their access to distance education (six statements), assessment of universities' distance education infrastructure (four statements), students' opinions of distance education (20 statements), and general level of satisfaction of students in relation to distance education. Because having questionnaires filled out face-to-face is not possible during the Covid-19 pandemic, the questionnaire was implemented via cell phones or computers with internet access by students in April 2020. Information about the survey was disseminated by means of student societies and social media. While evaluating these findings, it should be taken into account that the data of the study were collected online.
Data in the scope of this study were analysed using the SPSS (23) statistics programme. Descriptive statistics were used such as mean, standard deviation, frequency, and percentage to determine students' evaluation and satisfaction levels regarding distance education in the data analysis. Permit number 2486 was obtained from the Atılım University Human Research Ethics Board.

\section{Results}

Based on socio-demographic and descriptive data, $71.7 \%$ of the participants were women, $57.5 \%$ were from urban areas, and the great majority (94.9\%) lived with their families. In this study, in which students of 109 universities participated, the great majority $(85.9 \%)$ of students were from public universities, $65.4 \%$ were graduate students and $37.8 \%$ second-year students; $56.5 \%$ of participants were studying health sciences.

\section{Opportunities Students Have Under the Distance Education System}

Descriptive answers to questions regarding the possibilities of access to distance education is given in Table 2. Accordingly, $74.3 \%$ of students stated that they had access to the internet at home or at their workplace, $34.4 \%$ stated that their internet traffic quota was a maximum of $8 \mathrm{~GB}$, and $55.9 \%$ stated that they connected to the internet using their mobile phones. While $51.5 \%$ of participants indicated that they had computer problems while taking their classes, $57.9 \%$ indicated that their siblings also participated in virtual classrooms over the internet in their household.

- Table 3 shows the answers of university students participating in this study to questions regarding the distance education infrastructure of their universities and the functioning of distance education. Accordingly, $74.3 \%$ of students participating in this study do not have distance education classes in their universities, and $66.7 \%$ never had a distance education experience. While the most prevalent problems experienced by participants in their online courses were connection errors $(26.1 \%)$, failure in downloading courses notes 
Table 2. Description of participants' answers to possibilities of access to distance education

\begin{tabular}{|c|c|c|c|}
\hline & & $n$ & $\%$ \\
\hline \multirow{2}{*}{ Do you have access to the internet at home or at work? } & Yes & 3755 & 74.3 \\
\hline & No & 1297 & 25.7 \\
\hline \multirow[t]{4}{*}{ What is your monthly internet traffic quota? } & $\leq 8 \mathrm{~GB}$ & 1740 & 34.4 \\
\hline & $9-24 \mathrm{~GB}$ & 584 & 11.6 \\
\hline & $\geq 25 \mathrm{~GB}$ & 1653 & 32.7 \\
\hline & I don't know & 1075 & 21.3 \\
\hline \multirow[t]{5}{*}{ What device do you use to connect to the internet? } & Desktop computer & 154 & 3.0 \\
\hline & Laptop & 675 & 13.4 \\
\hline & Mobile phone & 2824 & 55.9 \\
\hline & Tablet & 29 & 0.6 \\
\hline & Multiple devices & 1370 & 27.1 \\
\hline \multirow[t]{2}{*}{ Do you have computer problems while following your classes? } & Yes & 2603 & 51.5 \\
\hline & No & 2449 & 48.5 \\
\hline \multirow[t]{2}{*}{ Do you have any siblings in your household that also follow their classes online? } & Yes & 2925 & 57.9 \\
\hline & No & 2127 & 42.1 \\
\hline
\end{tabular}

$(14.1 \%)$, screen freezes $(11.6 \%)$, and voice interruptions (9.5\%), as little as $6.3 \%$ stated that they did not have any issues whatsoever. Distance education classes are delivered asynchronously at universities of $58.5 \%$ of students participating in this study. While the most widely used online tool for distance education is Zoom at $34 \%$, it is followed by Google Meet at 26.2\%, Perculus at $8.2 \%$, and Adobe Connect and Skype.

\section{Students' Evaluations of the Problems and Competencies in the Distance Education System}

According to the opinions of the participants about the problems and competencies related to distance education, $42.7 \%$ of participants stated that the time of synchronous classes was partially convenient for their attendance to classes, and $70.5 \%$ stated that they were able to access class records if they missed a

Table 3. Participants answers to questions regarding distance education infrastructure.

\begin{tabular}{|c|c|c|c|}
\hline & & $n$ & $\%$ \\
\hline \multirow[t]{2}{*}{ Do you have distance education centres at your university? } & Yes & 3483 & 74.3 \\
\hline & No & 1299 & 25.7 \\
\hline \multirow[t]{2}{*}{ Have you ever received a distance education? } & Yes & 1681 & 33.3 \\
\hline & No & 3371 & 66.7 \\
\hline \multirow[t]{7}{*}{ What problem do you have most typically during connecting to your classes? } & Connection error & 1321 & 26.1 \\
\hline & Failure in downloading class notes & 710 & 14.1 \\
\hline & Screen freeze & 588 & 11.6 \\
\hline & Audio interruption & 480 & 9.5 \\
\hline & Insufficient quota & 75 & 1.5 \\
\hline & I don't have any problems & 317 & 6.3 \\
\hline & I experience all of these problems & 1558 & 6.3 \\
\hline \multirow[t]{3}{*}{ How do your distance education classes function? } & Asynchronously & 2954 & 58.5 \\
\hline & Synchronously & 1997 & 39.5 \\
\hline & Both & 101 & 2.0 \\
\hline
\end{tabular}


Table 4. Participants' opinions of the competencies of distance education.

\begin{tabular}{|c|c|c|c|}
\hline & & $n$ & $\%$ \\
\hline \multirow[t]{3}{*}{ Are times of synchronous classes offered suitable for your attendance? } & Yes & 1861 & 36.8 \\
\hline & Partially & 2157 & 42.7 \\
\hline & No & 1034 & 20.5 \\
\hline \multirow[t]{2}{*}{ Do you have the possibility of accessing class records if you are to miss classes? } & Yes & 3561 & 70.5 \\
\hline & No & 1491 & 29.5 \\
\hline \multirow{3}{*}{$\begin{array}{l}\text { In your opinion, are class materials (PDF, Word, PowerPoint class presentations, video, } \\
\text { image, articles, URL links, etc.) uploaded by teaching personnel sufficient? }\end{array}$} & Yes & 1746 & 34.6 \\
\hline & Partially & 1977 & 39.1 \\
\hline & No & 1329 & 26.3 \\
\hline \multirow[t]{3}{*}{ Do you have any problem with your access to resources regarding classes and homework? } & Yes & 1742 & 34.5 \\
\hline & Partially & 1454 & 28.8 \\
\hline & No & 1856 & 36.7 \\
\hline
\end{tabular}

class. Furthermore, $73.7 \%$ of participants found class materials uploaded by teaching personnel to the distance education system to be sufficient or partially sufficient, and $19.9 \%$ of those participants who did not find it to be sufficient stated that faceto-face education was more efficient. Additionally, $63.3 \%$ of participants stated that they had problems accessing resources in classes and their homework ( $\square$ Table 4).

Regarding class attendance, $32.4 \%$ of the participants stated that they attended their classes regularly, $41.5 \%$ partially, and $26.1 \%$ could not attend their classes. Among the reasons for not attending the classes was the internet and/or devicerelated problems. Other results showed that that distance education was not an effective learning method according to $67.3 \%$ of participants, $79.5 \%$ stated that distance teaching of classes adversely affected their motivation, and $73.8 \%$ attributed such decreased motivation to uncertainties associated with internships and practice issues; $55.3 \%$ of participants stated that no social support was provided to them by their respective universities (— Table 5).

Table 5. Participants' opinions about the problems of distance education.

\begin{tabular}{|c|c|c|c|}
\hline & & $n$ & $\%$ \\
\hline \multirow[t]{3}{*}{ Are you able to follow classes regularly? } & Yes & 1638 & 32.4 \\
\hline & Partially & 2096 & 41.5 \\
\hline & No & 1318 & 26.1 \\
\hline \multirow[t]{3}{*}{ Is distance education an effective method of learning? } & Yes & 466 & 9.2 \\
\hline & Partially & 1186 & 23.5 \\
\hline & No & 3400 & 67.3 \\
\hline \multirow[t]{2}{*}{ How does distance teaching of classes affect your motivation? } & Positive & 1034 & 20.5 \\
\hline & Negative & 4018 & 79.5 \\
\hline \multirow[t]{3}{*}{ Do uncertainties in internship and practical classes affect your motivation? } & Yes & 3730 & 73.8 \\
\hline & Partially & 749 & 14.8 \\
\hline & No & 573 & 11.3 \\
\hline \multirow{3}{*}{$\begin{array}{l}\text { Are you able to readily communicate your questions with and opinions of distance } \\
\text { education to concerned parties? }\end{array}$} & Yes & 1610 & 31.9 \\
\hline & Partially & 1524 & 30.1 \\
\hline & No & 1918 & 38.0 \\
\hline \multirow[t]{3}{*}{ Would you be willing to receive education via distance education from now on? } & Yes & 757 & 15.0 \\
\hline & Partially & 1139 & 22.5 \\
\hline & No & 3156 & 62.5 \\
\hline
\end{tabular}


Regarding the distance education process, $25.9 \%$ of participants stated that they were "unable to take advantage of life experiences and intellectual knowledge other than vocational knowledge of their lecturers" and that they "missed being in interaction and spending time with their peers." In comparison, $7.1 \%$ stated that they believed that the "inability in delivery of internship or vocational practice classes created a deficiency of knowledge," and $62.5 \%$ of participants stated that they did not want to have education via distance education in the future ( $\mathbf{\square}$ Table 5$)$.

\section{Satisfaction Levels of Students in the Distance Education System}

Participants were asked, "On a scale of 10, how would you assess your satisfaction with classes taught over the internet?" and the average score they gave was 4.4. Regarding whether participants' level of satisfaction varied depending on the type of the university where they study, the satisfaction level of the students is generally low. However, it is higher in foundation universities (score of 4.9) than in public universities (score of 4.3). Regarding whether the satisfaction level of participants varied depending on education level was lowest at 4.2 average scores about undergraduate education. Moreover, we found that for the field of study of the students, the students with the lowest level of satisfaction were students studying science (score of 4.0) (泟 Figures 1-3).

\section{Discussion and Conclusion}

The Council of Higher Education and universities began to take necessary precautions to fight the pandemic in Turkey, as was the case worldwide upon the emergence of the first case in China. In this study, the opportunities students had in the distance education system, what kinds of problems they faced, and their level of satisfaction are discussed, and it is aimed to raise awareness about improving the system in the future.

This study collected data from 5052 students enrolled in 109 universities out of a total of 207 universities in Turkey. This study contributes to the literature with valuable data that enable us to understand the pandemic from students' eyes. It provides crucial results for significant steps to be taken to reveal the effects of the decisions and strategies implemented by the Council of Higher Education on students at the beginning of the pandemic.

According to this study, although many students have internet access, they still lack the technical infrastructure to follow up on their classes. Technically, the great majority of students that have a computer or similar devices have to share these capabilities with other family members in their house-

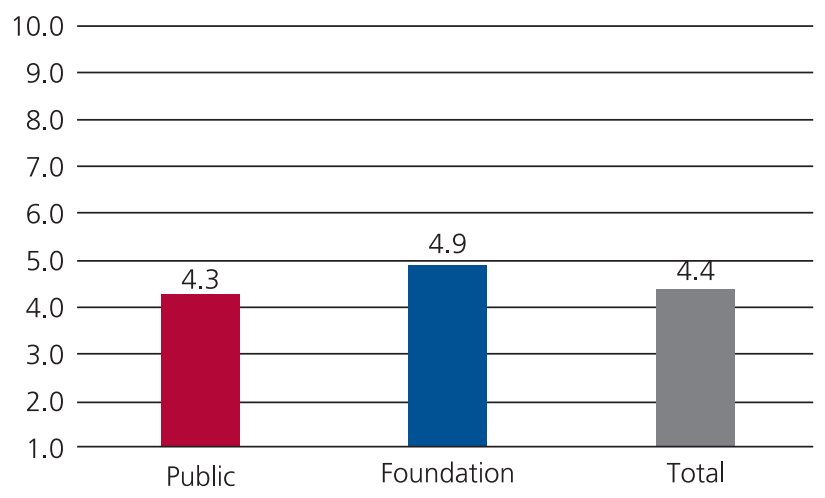

Figure 1. Comparison of satisfaction scores by public and foundation university (scala: 1-10).

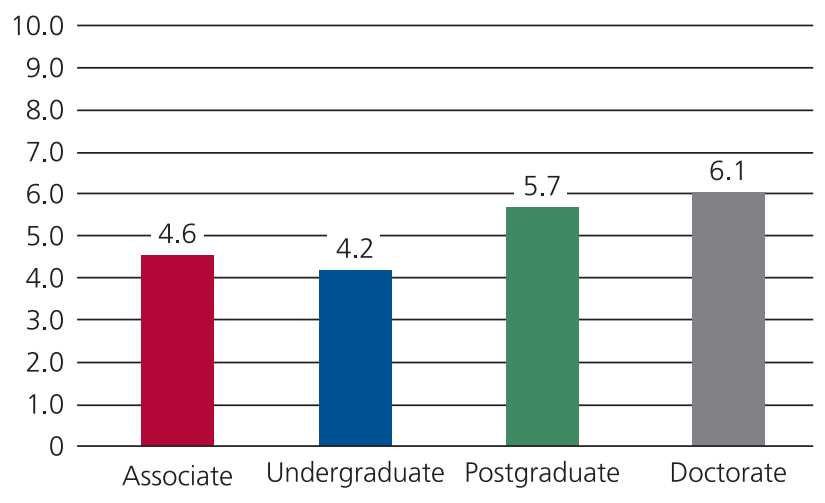

Figure 2. Comparison of satisfaction scores by education level (scala:110).

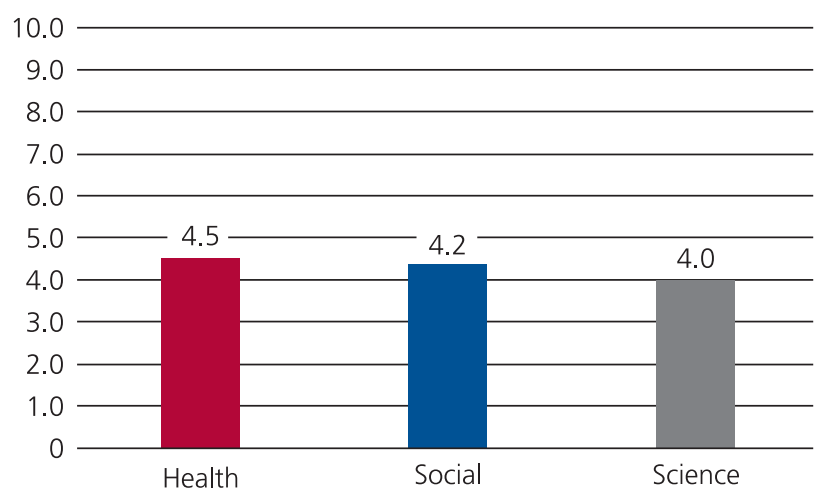

Figure 3. Comparison of satisfaction scores according to the students' education field (scala: 1-10).

holds. This is due to parents' working from home or siblings also receiving distance education in their household. Having a suitable internet connection and technical infrastructure and the ability to use it at the same time are prerequisites for effec- 
tive implementation of distance learning. A similar study conducted by Karadağ and Yücel (2020) on 17,939 students stated that only $63 \%$ of undergraduate students had an internet connection at home, and students did not have a computer or tablet. In synchronous and asynchronous attendance in classes, hardware and internet connection speed considerably affect the efficiency. However, results indicate that the great majority of students cannot meet this prerequisite. The study conducted by Karadağ and Yücel (2020) reported that one-fourth of the students within the scope of the study could not continue their education due to the lack of internet or a computer/tablet.

Distance education is a technology-based education method. Accordingly, the process is directly affected by issues such as either the students' or teachers' inability to make good or proper use of the internet or technology, and/or internet or power shortages (Ameen, Willis, Abdullah, \& Shah, 2019; Davidson, 2019; İnce, Kabul, \& Diler, 2020; Saeid \& Goodarzi, 2019). Even in the information age, it is evident that many individuals prove incompetent in terms of education technologies. Similar research carried out around the world indicates that although the young, in particular, are very efficient in internet and information technology use, they fail to demonstrate the same level of success when they use such capabilities for educational purposes (Tai, Bellingham, Lang, \& Dawson, 2019). For synchronous and asynchronous attendance in classes, hardware and internet connection speed considerably affect efficiency. However, results indicate that the great majority of students cannot meet this prerequisite. Similarly, a study conducted with chemistry students found that students were unequal in distance education due to their technical background (Danjou, 2020).

Another critical finding obtained from the research is the students' evaluation about problems and competencies related to the distance education system. Approximately 7 out of 10 students who participated in this research believe that distance learning is not an effective method. One of the factors that contributes to this opinion is the issue of uncertainties throughout the pandemic. Students are concerned that practical and internship classes cannot be delivered, although theoretical courses are online. Also, they did not know how long this pandemic would prevail. Approximately half of the participants of this study were students in health sciences. Internship and practical classes constitute the most crucial part of their education. Accordingly, in our opinion, uncertainty is a source of anxiety for students. A study conducted with students studying in different fields such as biology, nursing, business, and mathematics concluded that students were worried about distance learning being different from standard in-class learning
(Unger \& Meian, 2020). A study conducted with students studying health sciences in Brazil concluded that the quality of clinical practice and professional education in distance education would be impaired, and students were worried about failing during the academic year (Peloso et al., 2020). In a study carried out in Ukraine, the students stated that the lack of live communication, limited access to a computer, and the inadequacy of practice lessons were disadvantages of distance education (Prokopenko \& Berezhna, 2020).

It is evident that students experience problems in their journey with distance education, and some of these problems are associated with their technical infrastructure or internet capabilities, while others are related to the learning management system. Based on these issues, students state their dissatisfaction with the efficiency of distance education. The fact that classes are mostly delivered in an asynchronous manner, with teachers and students being in different settings, deprives the students of student-teacher interaction that is usually a component of conventional teaching. The fact that the most widely criticised aspect of distance education in literature is the low level of student-teacher interaction (Durak et al., 2017) further affirms the findings of this study. In a study conducted in Pakistan, students emphasised that a low level of teacher-student interaction and the lack of socialisation in the classroom is the most critical deficiency of distance education (Adnan \& Anwar, 2020). According to the results of a qualitative study conducted with students on the advantages and disadvantages of distance education during the pandemic, students stated that distance education was valuable but not as much as classroom learning (Hebebci, Bertiz, \& Alan, 2020).

Although the Council of Higher Education's open class platform was established in this system, it is evident that students do not have sufficient motivation to use class materials developed by various teaching personnel. We believe that asynchronous classes that consist of merely video recordings coupled with the class and class material that are incompatible, adversely affect the learning process. A study conducted in Iran showed that Iranian medical students faced some challenges with e-learning, such as high volume of content, lack of interaction with professors, weak support system, weak management of the e-learning system, and low motivation (Afshari et al., 2020).

Teachers and students are two critical components of distance education. The teacher must be able to make effective use of teaching techniques and technologies and have the information and skills required for traditional education as well as the vision and capabilities to continuously develop these skills (Adnan, Kalelioglu, \& Gulbahar, 2017). This aspect of 
the teacher emerges as one factor that affects the students' satisfaction in distance education. In this process, students and teachers are responsible for the learning process more than in the conventional method. Techniques of teaching and learning go through a rapid change in parallel to distance learning. The success of the process depends on both parties' compatibilities with the process and their interaction (Kırık, 2014).

In this context, individual and cultural differences are essential factors from the students' perspective about distance education. A study conducted in Pakistan showed that students of different ethnic origins had difficulties adapting to an online system and that they tended to do their homework at the last minute (Jayatilleke \& Gunawardena, 2016). From the students' point of view, the achievement of desired success in distance education depends on students being sufficiently ready and competent for online learning and the learning style (Gülbahar \& Alper, 2014; Ilgaz \& Gülbahar, 2015).

Chaney and others (2007) examined 160 articles and 20 books in a systematic analysis and found 14 quality indicators in the literature for distance education. These were studentteacher interaction, instant feedback, technical support service, class programme, technology, institutional support and institution resources, structured class guide, active learning techniques, supervision of various learning methods, faculty support services, institutions' current distance education missions, suitable tools and environment, reliability and technology, course development, and guidance practices for review of learning materials.

One of the crucial findings of this study is that student satisfaction is very low in distance learning. The above findings obtained from students in the scope of this study explain why the level is so low. Although there is a difference between the levels of satisfaction in public universities (4.3) and foundation universities (4.9), the overall satisfaction (4.4) is very low. The difference in ownership status may have made a difference in terms of administrative differences, the number of students, and compliance with the process. The education setting and the number of students present in the environment also affect the education efficiency of online education. Online education studies conducted with small groups indicate that students can get to know each other more closely, and the compliance is higher within the group compared to smaller groups (Akcaoglu \& Lee, 2016). Karadağ and Yücel (2020) revealed that the mean scores of the factors indicating student satisfaction ranged from 3.73 to 2.63. The dimension students are most satisfied with is "Satisfaction with the Council of Higher Education," and the two dimensions students are the least satisfied with are "Satisfaction with the University and Faculty Management" and "Satisfaction with the Digital Content/Instructional Materials."

Perception of satisfaction was found to be higher with students that had prior distance education experience. It may be that their prior experiences with and expectations from the process affected their satisfaction and helped them to adapt quickly. Contrary to what would be expected, the level of satisfaction did not differ based on whether universities have a distance education centre (DEC). It would typically be expected that universities that have distance education centres can manage the process more effectively and adapt more quickly, which would, in turn, affect the level of satisfaction of students. However, this study did not yield the expected result. This can be explained as the Council of Higher Education's making available the knowledge, experience, infrastructure, and resources for common use in inclusive coordination (Saraç, 2020) and aligning all universities together regardless of such universities' having a DEC or not. This may be the reason why levels of student satisfaction were not affected by this variable. As a result of the study carried out by Karadağ and Yücel (2020), $63 \%$ of the students were satisfied with the decisions taken by the Council of Higher Education during the pandemic at a "good" and "very good" level.

Another important finding that is noteworthy in this study is that many students did not exercise their right to suspend registration despite the low level of satisfaction and many problems encountered in the process. Students wanted to continue their education despite all the negativities that they mentioned.

Education and learning of all levels were affected by Covid19 in all countries, inevitably creating alternative solutions. In this scope, many programmes offering instruction in health and social and life sciences have developed many innovative methods, although they cannot fully substitute face-to-face education (Plancher, Shanmugam, \& Petterson, 2020). For instance, reverse education method practices, teleconference, and telemedicine-based simulations can mitigate learning losses in types of practical education such as surgery education (Connor et al., 2020).

In conclusion, whether we like it or not, the world will not revert to pre-Covid-19 days. For this reason, distance education has to be a part of the universities' education processes. Based on this reality, many responsibilities await us all as students, educators, and institutions. Students must develop their individual and technical infrastructures, learning behaviours, and strategies towards adapting to change. Teachers must follow up on technological advancements that align with their teaching achievements and develop new teaching strategies as alternatives to conventional methods. On the other hand, insti- 
tutions must establish an infrastructure that can address new needs to facilitate technology compliance and switch to new operation methods. There will be a world that is constructed by those who can adapt rapidly to these changing and challenging effects in the future.

It would be beneficial if universities rapidly identified issues originating from distance education methods to increase students' satisfaction while the government offered discounts and incentives targeting students and teaching personnel concerning the internet infrastructure and access to the internet. Moreover, universities must complete infrastructural preparations and take measures needed for switching to synchronous education and research systems that can increase the security of exam systems.

Yazar Katkıları / Author Contributions: OI: Tasarım, danışmanlık/denetleme, kaynak taraması, makalenin yazılması, veri analizi, bulguların yorumlanması, eleştirel inceleme ve makalenin son kontrolü; DT: Fikir, danışmanlık/denetleme, bulguların yorumlanması, kaynak taraması, makalenin yazılması, eleştirel inceleme ve makalenin son kontrolü; PŞT: Danışmanlık/denetleme, kaynak taraması, makalenin yazılması, eleştirel inceleme ve makalenin son kontrolü; NT: Danışmanlık/denetleme, veri toplanması, kaynak taraması, makalenin yazılması, eleştirel inceleme ve makalenin son kontrolü; AZ: Danışmanlık/denetleme, bulguların yorumlanması, kaynak taraması, makalenin yazılması, eleştirel inceleme ve makalenin son kontrolü. / OI: Conceiving and designing the study, study monitoring, literature search, writing manuscript, data analysis, interpreting the results, critical reading and final check of the manuscript; DT: Project idea, study monitoring, interpreting the results, literature search, writing manuscript, critical reading and final check of the manuscript; PŞT: Study monitoring, literature search, writing manuscript, critical reading and final check of the manuscript; NT: Study monitoring, data collection, literature search, writing manuscript, critical reading and final check of the manuscript; AZ: Study monitoring, interpreting the results, literature search, writing manuscript, critical reading and final check of the manuscript.

Araştırma Fonu Desteği / Funding: Bu çalışma herhangi bir resmi, ticari ya da kar amacı gütmeyen organizasyondan araştırma fonu desteği almamiştır. I This research did not receive any specific grant from funding agencies in the public, commercial, or not-for-profit sectors.

Etik Standartlara Uygunluk / Compliance with Ethical Standards: Yazarlar bu makalede araştırma ve yayın etiğine bağlı kalındığını, Kişisel Verilerin Korunması Kanunu'na ve fikir ve sanat eserleri için geçerli telif hakları düzenlemelerine uyulduğunu ve herhangi bir çıkar çakışması bulunmadığını belirtmiştir. / The authors stated that the standards regarding research and publication ethics, the Personal Data Protection Law and the copyright regulations applicable to intellectual and artistic works are complied with and there is no conflict of interest.

\section{References}

Adnan, M., \& Anwar, K. (2020). Online learning amid the COVID-19 pandemic: Students' perspectives. Fournal of Pedagogical Sociology and Psychology, 2(1), 45-51.

Adnan, M., Kalelioglu, F., \& Gulbahar, Y. (2017). Assessment of a multinational online faculty development program on online teaching: Reflections of candidate e-tutors. Turkish Online fournal of Distance Education, 18(1), 22-38
Afshari, P., Abedi, P., Eslami, K., Rokhafrooz, D., Maraghi, E., \& Beheshtinasab, M. (2020). The views of medical students about e-learning during pandemic of COVID-19 in Iran. Research Square, [Preprint v1]. doi: $10.21203 /$ rs.3.rs- $47582 / v 1$

Akcaoglu, M., \& Lee, E. (2016). Increasing social presence in online learning through small group discussions. The International Review of Research in Open and Distributed Learning, 17(3). doi:0.19173/irrodl.v17i3.2293

Ali, W. (2020). Online and remote learning in higher education institutes: A necessity in light of COVID-19 pandemic. Higher Education Studies, 10(3), 16-25.

Ameen, N., Willis, R., Abdullah, M. N., \& Shah, M. (2019). Towards the successful integration of e-learning systems in higher education in Iraq: A student perspective. British Fournal of Educational Technology, 50(3), 1434-1446.

Chaney, B. H., Eddy, J. M., Dorman, S. M., Glessner, L., Green, B. L., \& Lara-Alecio, R. (2007). Development of an instrument to assess student opinions of the quality of distance education courses. The American Fournal of Distance Education, 21(3), 145-164.

Cochran, W. G. (1977). Sampling techniques. New York, NY: Wiley.

Connor, R., Guy, C., Peace, K. M., Propper, B. W., Hale, D. F., Alseidi, A. A., \& Vreeland, T. J. (2020). Using technology to maintain the education of residents during the COVID-19 pandemic. Fournal of Surgical Education, 77(4), 729-732.

Danjou, P. E. (2020). Distance teaching of organic chemistry tutorials during the COVID-19 pandemic: Focus on the use of videos and social media. Fournal of Chemical Education, 97(9), 3168-3171.

Davidson, P. (2019). Future online faculty competencies: Student perspectives. International Fournal on E-Learning, 18(3), 233-250.

Després-Bedward, A., Avery, T., \& Phirangee, K. (2018). Student perspectives on the role of the instructor in face-to-face and online learning. International fournal of Information and Education Technology, 8(10), 706-712.

Durak, G., Çankaya, S., Yünkül, E., \& Bozkurt, A. (2017). 5İ derslerini uzaktan eğitimle alan öğrencilerin görüşleri. VII. Uluslararası Ĕ̆itimde Araştırmalar Kongresi ULEAD 2017 Annual Congress (s. 89), April 27-29, 2017, Çanakkale.

Gülbahar, Y., \& Alper, A. (2014). Development of e-learning styles scale for electronic environments. [Article in Turkish] Egitim ve Bilim, 39(171), 421-435.

Hebebci, M. T., Bertiz, Y., \& Alan, S. (2020). Investigation of views of students and teachers on distance education practices during the Coronavirus (COVID-19) pandemic. International fournal of Technology in Education and Science (IFTES), 4(4), 267-282.

Ilgaz, H., \& Gülbahar, Y. (2015). A snapshot of online learners: eReadiness, e-satisfaction and expectations. International Review of Research in Open and Distributed Learning, 16(2), 171-187.

İnce, E. Y., Kabul, A., \& Diler, İ. (2020). Distance education in higher education in the COVID-19 pandemic process: A case of Isparta Applied Sciences University. Distance Education, 4(4), 343-351.

Jayatilleke, B. G., \& Gunawardena, C. (2016). Cultural perceptions of online learning: transnational faculty perspectives. Asian Association of Open Universities fournal, 11(1), 50-63.

Karadă̆, E., \& Yücel, C. (2020). Yeni tip Koronavirüs pandemisi döneminde üniversitelerde uzaktan eğitim: Lisans öğrencileri kapsamında bir değerlendirme çalışması. Yiikseköğretim Dergisi, 10(2), 181-192. 
Kırık, A. M. (2014). Historical development of distance education and the situation in Turkey. [Article in Turkish] Marmara İletişim Dergisi, (21), 73-94.

Peloso, R. M., Ferruzzi, F., Mori, A. A., Camacho, D. P., Franzin, L. C. D. S., Margioto Teston, A. P., \& Freitas, K. M. S. (2020). Notes from the field: concerns of health-related higher education students in Brazil pertaining to distance learning during the Coronavirus pandemic. Evaluation \& the Health Professions, 43(3), 201-203.

Plancher, K. D., Shanmugam, J. P., \& Petterson, S. C, (2020). The changing face of orthopedic education: Searching for the new reality after COVID-19. Arthroscopy, Sports Medicine, and Rehabilitation, 2(4), e295- e298.

Prokopenko, I., \& Berezhna, S. (2020). Higher education institutions in Ukraine during the Coronavirus, or COVID-19, outbreak: New challenges vs new opportunities. Revista Romaneasca Pentru Educatie Multidimensionala, 12(1Sup2), 130-135.
Saeid, N., \& Goodarzi, M. (2019). Applying path analysis model in explaining the factors affecting the quality and usefulness of e-learning: The students' perspective. Interdisciplinary Fournal of Virtual Learning in Medical Sciences, 10(3), 11-22.

Saraç, M. Y. (2020). Pandemi günlerinde Türk Yükseköğretimi: Uzaktan eğitim yoğun kulanımda [Article in Turkish]. YÖK Yiiksek Öğretim Dergisi, 16, 6-9.

Tai, J. H.-M., Bellingham, R., Lang, J., \& Dawson, P. (2019). Student perspectives of engagement in learning in contemporary and digital contexts. Higher Education Research \& Development, 38(5), 1075-1089.

Unger, S., \& Meiran, W. (2020). Student attitudes towards online education during the COVID-19 viral outbreak of 2020: Distance learning in a time of social distance. International fournal of Technology in Education and Science, 4(4), 256-266.

Zhou, M. (2016). Chinese university students' acceptance of MOOCs: A self-determination perspective. Computers \& Education, 92-93, 194203.

Bu makale Creative Commons Attribution-NonCommercial-NoDerivs 4.0 Unported (CC BY-NC-ND 4.0) Lisansi standartlarında; kaynak olarak gösterilmesi koşuluyla, ticari kullanım amacı ve içerik değişikliği dışında kalan tüm kullanım (çevrimiçi bağlantı verme, kopyalama, baskı alma, herhangi bir fiziksel ortamda çoğaltma ve dağıtma vb.) haklarılla açık erişim olarak yayımlanmaktadır. / This is an open access article distributed under the terms of the Creative Commons AttributionNonCommercial-NoDerivs 4.0 Unported (CC BY-NC-ND 4.0) License, which permits non-commercial reuse, distribution and reproduction in any medium, without any changing, provided the original work is properly cited.

Yayıncı Notu: Yayıncı kurulus olarak Deomed bu makalede ortaya konan görüșlere katılmak zorunda değildir; olası ticari ürün, marka ya da kuruluşlarla ilgili ifadelerin içerikte bulunmas yayıncının onayladığı ve güvence verdiği anlamına gelmez. Yayının bilimsel ve yasal sorumlulukları yazar(lar)ına aittir. Deomed, yayınlanan haritalar ve yazarların kurumsal bă̆lantıları ile ilgili yarg1 yetkisine ilişkin iddialar konusunda tarafsizdır. / Publisher's Note: The content of this publication does not necessarily reflect the views or policies of the publisher, nor does any mention of trade names, commercial products, or organizations imply endorsement by Deomed. Scientific and legal responsibilities of published manuscript belong to their author(s). Deomed remains neutral with regard to jurisdictional claims in published maps and institutional affiliations. 